\title{
Sirenomelia Sequence and Malposition of the Penis
}

\author{
Sirenomelia Sekansi ve Penis Malpozisyonu
}

\author{
Ali KARAMAN, Halil KESKIN², Ebru KAÇMAZ², Filiz KESKIN², Fuat LALOĞLU², Remzi ARSLAN
}

\author{
1Erzurum Nenehatun Obstetrics and Gynecology Hospital, Department of Medical Genetics, Erzurum, Turkey \\ 2Erzurum Nenehatun Obstetrics and Gynecology Hospital, Neonatal Intensive Care Unit, Erzurum, Turkey \\ ${ }^{3}$ Erzurum Nenehatun Obstetrics and Gynecology Hospital, Department of Pathology, Erzurum, Turkey
}

\begin{abstract}
Sirenomelia is a rare anomaly of the caudal region of the body, presenting with fusion of the lower limbs. Genitourinary, gastrointestinal, neural tube and vertebral anomalies are found in most cases. Herein, a very rare case with the sirenomelia sequence is presented. The patient had fusion of both lower limbs, absent genitalia, absent anal orifice, absent ureteral orifice, pelvic and sacral dysplasia and a single umbilical artery. In addition, he had a malpositioned penis in the posterior sacral area. He died 11 hours after birth.
\end{abstract}

Key Words: Malposition of the penis, Oligohydramnios, Sirenomelia

\section{ÖZET}

Sirenomelia alt ekstremitelerin yapışıklığı ile seyreden, vücudun kaudal bölgesinin nadir bir anomalisidir. Çoğu olguda genitouriner, gastrointestinal, nöral tüp ve vertebra anomalileri bulunur. Bu yazıda, sirenomelia sekansı gösteren çok nadir bir olgu sunulmuştur. Hasta yapışı alt ekstremiteye, genital organ yokluğuna, anal orifis yokluğuna, pelvik ve sakral displaziye ve tek umbilikal artere sahipti. Illaveten posteriyor sakral bölgede malpozisyonlu penisi vardl. Hasta doğumundan 11 saat sonra öldü.

Anahtar Sözcükler: Penis malpozisyonu, Oligohidroamnios, Sirenomeli

\section{INTRODUCTION}

Sirenomelia (mermaid baby) sequence is a very rare developmental defect of the posterior axis caudal blastima with a reported incidence of $1 / 100,000$ live births (1). The condition is usually fatal (2). It is characterized by the fusion of both lower limbs, absent genitalia and anal orifice and renal agenesis (3). Etiology is unknown with male gender predominance. The prenatal diagnosis of sirenomelia by ultrasonography and threedimensional helical computed tomography (3D-CT) is possible (4-6). Herein we report a newborn with sirenomelia sequence, single umbilical artery and malpositioned penis in the posterior sacral area.

\section{CASE REPORT}

A 36-year-old mother (gravida 4, para 3) delivered a baby at the gestational age of 29 weeks. The body weight of the baby was $1270 \mathrm{gr}$. The father was 30 years old. The parents were not consanguineous. On - physical examination, the case had scaphocephaly, high arch cleft palate, low-set ears, fusion of both lower limbs, absent genitalia, absent anal orifice, absent ureteral orifice and single umbilical artery (Figure 1A,B.). Furthermore, the patient had malposition of the penis in the posterior sacral area (Figure 2). X-ray of the case revealed two broad femurs, two broad tibias and two broad fibulas (Figure 3). Ultrasound of the cranium and abdomen showed minimal dilated lateral ventricles, and bilateral ectopic multicystic dysplastic kidneys and absence of the bladder, respectively. The echocardiogram revealed small secundum type of atrial septal defect. The case developed severe respiratory distress after birth, and was transferred to the neonatal intensive care unit and died within 11 hours. Karyotyping of lymphocytes obtained from peripheral blood with GTG banding was normal $(46, \mathrm{XY})$. Autopsy was not accepted by the family. 

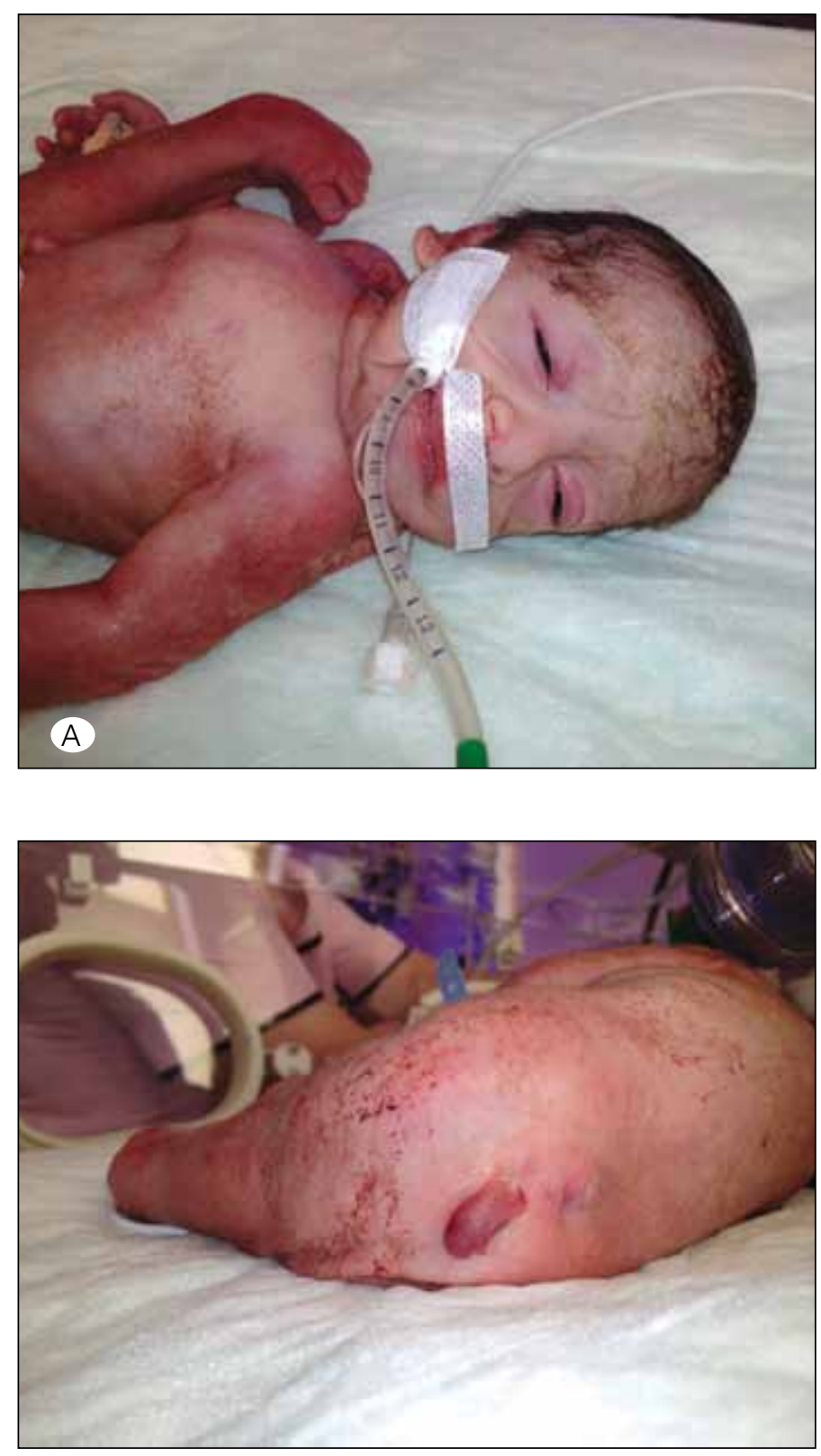

Figure 2: Posterior view of the patient showing malposition of the penis in the posterior sacral area and absent anal opening.

\section{DISCUSSION}

The cause of sirenomelia remains unclear but maternal diabetes mellitus, genetic predisposition, environmental factors and vascular steal phenomenon with the single vitelline umbilical artery diverting blood supply and nutrients from the lower body and limbs have been proposed as possible causative factors (7-10). The pattern of birth defects seen in sirenomelia is associated with abnormal umbilical cord blood vessels. Most babies with sirenomelia have only one umbilical artery and one vein, as was seen in our patient. His mother did not have either diabetes mellitus or gestational diabetes. During pregnancy, the mother had no known exposure to teratogens

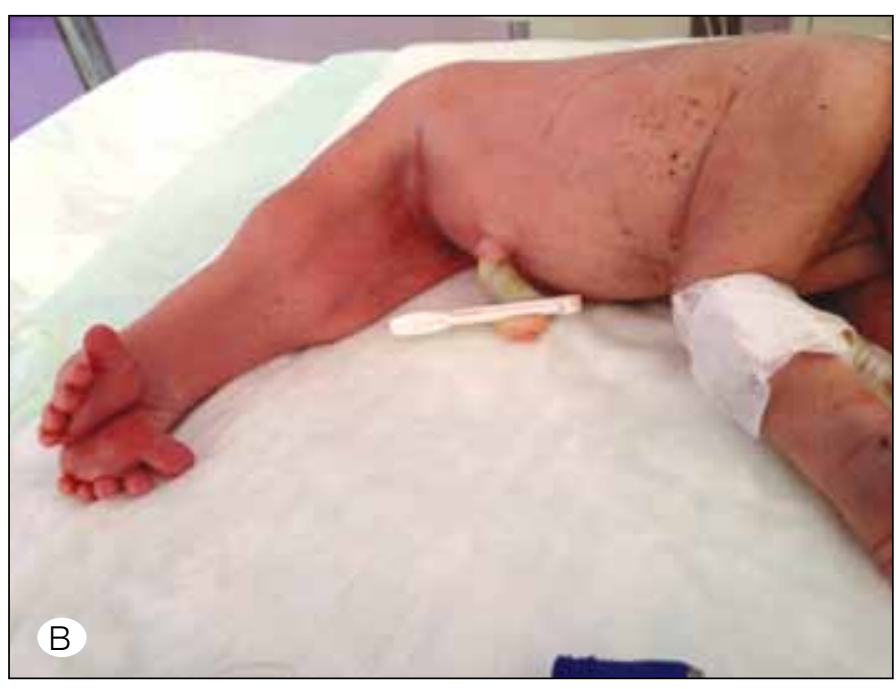

Figure 1: A) The facial appearance of the patient with sirenomelia. B) Anterior view of the patient showing fused lower limbs, absent external genitalia and urinary orifice.

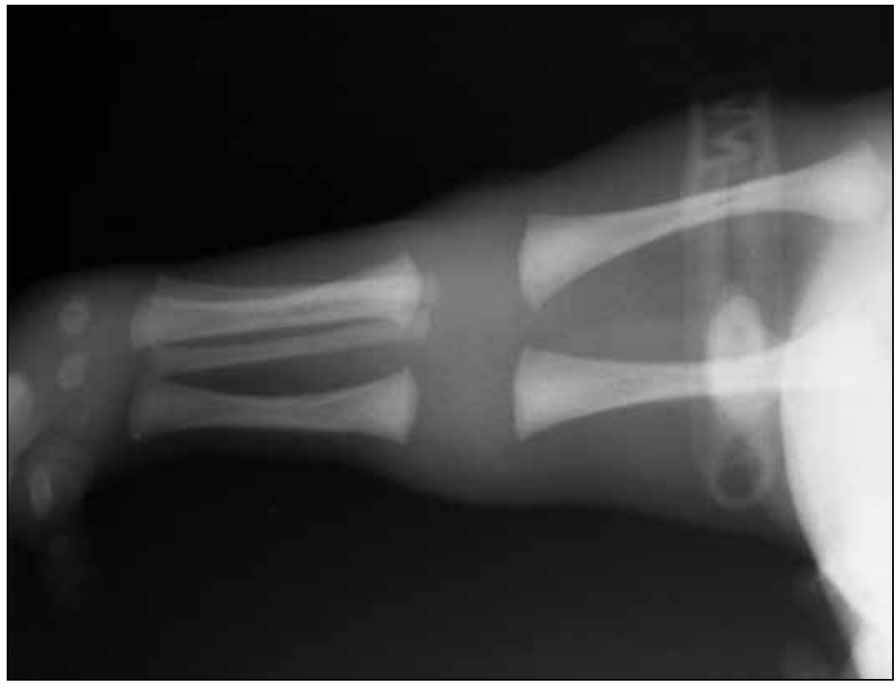

Figure 3: X-ray of the lower limbs showing two broad femurs, two broad tibias and two broad fibulas.

such as cocaine, retinoic acid, cyclophosphamide, cadmium and organic solvents.

The spectrum of malformation of the lower limbs seen in babies with sirenomelia ranges from fusion of the legs into one lower limb with only two bones present in the entire limb (a femur and a tibia) and absence of foot structures to fusion of the skin of the lower limbs along the inner leg with fully formed and separate lower limb bones and fully formed feet which are fused at the ankles. In this paper, we report an unusual coincidence of sirenomelia sequence and malposition of the penis that has been described in only two cases previously $(11,12)$. Sirenomelia has been classified into seven types by Stocker and Heifetz (13). According to this classification, our 
case had type 1 sirenomelia. The case had two broad femurs, two broad tibias and two broad fibulas.

The vascular steal theory was initially suggested in 1927 by Kampmeier and was called "nutritional deficit". This theory was reintroduced in 1986 by Stevenson under the term "vascular steal" (14). Stevenson relied on observations taken from the autopsies of some cases of sirenomelia, which determined that the blood returns to the placenta through a large vessel derived from the vitelline artery and starting from the abdominal aorta (just under the diaphragm). The abdominal aorta does not give any collateral. A mega-artery ensures the function of both umbilical arteries and diverts the blood flow on the embryo's caudal extremity toward the placenta, causing a nutritional deficit and a lack of development of the caudal extremity. Sirenomelia is quite often accompanied by a unique umbilical artery (13). Our observation of a single umbilical artery and dysplastic kidneys might support this theory. The vascular steal theory also fails to explain the frequent association of sirenomelia with other abnormalities such as cranial, cardiac, esophageal and genital defects $(12,15)$.

Controversy still exists on whether sirenomelia is a severe form of caudal regression syndrome and VACTERL (vertebral defects, anorectal atresia, cardiac abnormalities, tracheooesophageal fistula, renal and limb abnormalities) association due to overlapping features (7-9).

The diagnosis is obvious at birth by examination of the baby, but prenatal diagnosis can also be made as early as the first trimester by ultrasonography $(16,17)$. Similarly, threedimensional helical computed tomography (3D-CT) is helpful for making a prenatal diagnosis of sirenomelia in the second or third trimester despite the presence of severe oligohydramnios. In particular, 3D-CT appears to be more effective for evaluation of the skull, ribs, pelvis and vertebrae, as well as for assessing bone mineralization $(18,19)$.

To our knowledge this is the second report of an association coincidence of the sirenomelia sequence and malposition of the penis. As it is possible to demonstrate sirenomelia, a lethal anomaly, at as early as the 20th week of pregnancy, an early diagnosis could be useful in terminating the pregnancy.

\section{REFERENCES}

1. Kallen B, Castilla EE, Lancaster PA, Mutchinick O, Knudsen LB, Martinez-Frias ML, et al. The cyclops and the mermaid: An epidemiological study of two types of rare malformation. J Med Genet 1992;29:30-5.

2. Taori KB, Mitra K, Ghonga NP, Gandhi RO, Mammen T, Sahu J. Sirenomelia sequence (mermaid): Report of three cases. Indian J Radiol Imaging 2002;12:399-401.
3. Jones KL. Sirenomelia sequence. In:Smith's Recognizable Patterns of Human Malformation. 6th ed. Philadelphia: Elsevier Saunders, 2006:728-9.

4. Akbayır O, Gungorduk K, Sudolmuş S, Gulkllık A, Ark C. First trimester diagnosis of sirenomelia: $A$ case report and review of the literature. Arch Gynecol Obstet 2008;278:589-92.

5. Clemente CM, Farina M, Ciancı A, Iracı Sareri M. Sirenomelia with oligodactylia: Early ultrasonographic and hysteroscopic embryoscopic diagnosis during the first trimester of gestation. Fetal Diagn Ther 2010;8:43-5.

6. Contu R, Zoppi MA, Axiana C, Ibba RM, Monni G. First trimester diagnosis of sirenomelia by 2D and 3D ultrasound. Fetal Diagn Ther 2009;26:41-4.

7. Assımakopoulos E, Athanasiadis A, Zafrakas M, Dragoumıs K, Bontis J. Caudal regression syndrome and sirenomelia in only one twin in two diabetic pregnancies. Clin Exp Obstet Gynecol 2004;31:151-3.

8. Kadian YS, Duhan N, Rattan KN, Rawal M. Sirenomelia (mermaid syndrome): A rare anomaly. Afr J Paediatr Surg 2008;5:105-6.

9. Tanha FD, Googol N, Kaveh M. Sirenomelia (mermaid syndrome) in an infant of a diabetic mother. Acta Medica Iranica 2003;41:69-72.

10. Stevenson RE, Jones KL, Phelan MC, Jones MC, Barr M Jr, Clericuzio C, et al. Vascular steal: The pathogenetic mechanism producing sirenomelia and associated defects of the viscera and soft tissues. Pediatrics 1986;78:451-7.

11. Currarino $G$, Weinberg A. From small pelvic outlet syndrome to sirenomelia. Pediatr Pathol 1991;11:195-210.

12. Bakhtar O, Benirschke K, Masliah E. Sirenomelia of an intracytoplasmic sperm injection conceptus: A case report and review of mechanism. Pediatr Dev Pathol 2006;9:245-53.

13. Stockers JT, Heifetz SA. Sirenomelia: A morphological study of 33 cases and review of the literature. Perspect Pediatr Pathol 1987;10:7-50.

14. Stevenson RE, Jones KL, Phelan MC, Jones MC, Barr M Jr, Clericuzio C, et al. Vascular steal: The pathogenic mechanism producing sirenomelia and associated defects of viscera and soft tissues. Pediatrics 1986;78:451-7.

15. Valenzano M, Paoletti R, Rossi A, Farinini D, Garlaschi G, Fulcheri E. Sirenomelia. Pathological features, antenatal ultrasonographic clues and a review of current embryogenic theories. Hum Reprod Update 1999;5:82-6.

16. Guven MA, Uzel M, Ceylaner S, Coskun A, Ceylaner G, Gungoren A. A prenatally diagnosed case of sirenomelia with polydactyly and vestigial tail. Genet Couns 2008;19:419-24.

17. Van Keirsbilck J, Cannie M, Robrechts C, de Ravel T, Dymarkowskı $\mathrm{S}$, Van den Bosch T, et al. First trimester diagnosis of sirenomelia. Prenat Diagn 2006;26:684-8.

18. Ono T, Katsura D, Tsujı S, Yomo H, Ishiko A, Inoue T, et al. Prenatal diagnosis of sirenomelia in the late second trimester with threedimensional helical computed tomography. Tohoku J Exp Med 2011;225:85-7.

19. Ruano R, Molho M, Roume J, Ville Y. Prenatal diagnosis of fetal skeletal dysplasias by combining two-dimensional and threedimensional ultrasound and intrauterine three-dimensional helical computer tomography. Ultrasound Obstet Gynecol 2004;24: 134-40. 